\title{
Effects of hypoglycaemia on early embryogenesis in rat embryo organ culture
}

\author{
S. Akazawa, M. Akazawa, M. Hashimoto, Y. Yamaguchi, N. Kuriya, K. Toyama, Y.Ueda, T. Nakanishi, T. Mori, \\ S. Miyake and S. Nagataki \\ First Department of Internal Medicine, Nagasaki University School of Medicine, Nagasaki, Japan
}

Summary. As congenital malformations may be caused by perturbations of glycolytic flux on early embryogenesis [16], effects of hypoglycaemia were investigated by using rat embryo organ culture. Nine and one-half day old rat embryos were grown in vitro for $48 \mathrm{~h}$ (day $9 \frac{1}{2}$ to $11 \frac{1}{2}$ ) in the presence of hypoglycaemic serum for different hours during the culture period. Hypoglycaemic serum was obtained from rats given insulin intraperitoneally. On exposure to hypoglycaemic serum during the first $24 \mathrm{~h}$ of culture (day $9 \frac{1 / 2}{2}$ to $10 \frac{1}{2}$ ), embryos showed marked growth retardation and had increased frequencies of neural lesions ( $42.7 \%$ versus $0 \%, p<$ 0.01 ), in contrast to hypoglycaemic exposure during the second $24 \mathrm{~h}$ of culture (day $10 \frac{1}{2}$ to $11 \frac{1}{2}$ ), where only minor growth retardation and low frequencies of neural lesions $(2.4 \%$ versus $0 \%, \mathrm{NS})$ were seen. Even exposure to hypogly- caemic serum for a relatively short period $(8 \mathrm{~h})$ during the first $24 \mathrm{~h}$ of culture resulted in neural lesions at the frequency of $9.3-13.3 \%$. The embryos exposed to hypoglycaemia demonstrated decreased glucose uptake and lactic acid formation, indicating decreased energy production via glycolysis that constitutes the principal energy pathway at this stage of embryonic development. These results suggest that hypoglycaemia during critical periods of embryogenesis has adverse effects on the development of the embryo and these effects might be mediated through metabolic interruption of embryogenesis.

Key words: Hypoglycaemia, rat embryo culture, congenital malformation, growth retardation.
It is generally accepted that infants of insulin-dependent diabetic mothers have a higher incidence of congenital malformations [1-4]. A number of experiments of streptozotocin-induced diabetic animals $[5,6]$ and studies in humans $[7,8]$ have suggested that metabolic abnormalities such as hyperglycaemia in early pregnancy may be important factors causing congenital malformations. Whole embryo organ culture techniques in rodents, in which the embryo can develop from early head-fold stage to tail-bud stage with 26-30 somites have been developed [9, 10]. The morphogenetic events that occur in cultured embryos correspond to periods observed in human embryos during the 3rd-6th weeks of gestation which is the most susceptible period of teratogenesis in diabetic patients. It has been shown that the addition of excess glucose $[11,12]$ or ketone bodies $[13,14]$ to the culture medium have had teratogenic effects on cultured rat or mouse embryos.

On the other hand, effects of hypoglycaemia, during early embryogenesis remain to be evaluated. Since the embryo during the early phase of organogenesis is critically dependent on glycolysis and inhibition of glycolytic flux during the early periods resulting in dysmorphogenesis $[15,16]$, maternal hypoglycaemia during the vulnerable periods could be harmful to the embryo. Therefore, rat embryo organ culture was employed to test whether hypoglycaemia was associated with demonstrable abnormalities even during early embryogenesis and to determine its temporal relationships by exposure to hypoglycaemia for different hours during the culture period.

\section{Materials and methods}

Embryo culture techniques were performed by the methods of New [9] and detailed methods have been previously described [16]. Embryos were obtained from randomly bred Wistar rat (Shizuoka Laboratory Animal Center, Shizuoka, Japan) on day 91/2. (Pregnancy was timed from midnight preceding the morning when sperm were present in the varginal smear.) On day $9 \frac{1}{2}$ of gestation with the embryo at the early head-fold stage, gravida were killed by cervical dislocation. Conceptus were excised, floated in Petri dishes containing Hanks' balanced salt solution (Gibco, Grand Island, NY, USA) and freed of dicidua with a fine jeweler's forceps under direct visualisa- 
tion with a dissecting microscope. Reichert's membrane was opened and intact embryo units (i.e. embryos together with their visceral yolk sac, amnion, and ectoplacental cone) were explanted into culture media. Culture medium for normal conditions consisted of immediately centrifuged, heat-inactivated serum [9] from normal female rats combined in the proportion of $3: 1$ with isotonic $(0.85 \%)$ saline $(75 \% \mathrm{NRS})$ to give a final glucose concentration of $1100-1200 \mathrm{mg} / 1$.

Hypoglycaemic culture medium was obtained from normal female rats injected with insulin (Actrapid, NOVO Industry A/S, Bagsvaerd, Denmark; $1 \mathrm{u} / 100 \mathrm{~g}$ body weight) in which glucose levels were being monitored by a glucose autoanalyser (Beckman Instruments, Inc., Fullerton, Calif, USA) and treated as described above and combined in the proportion of 3:1 with saline as normal serum, to give final glucose concentrations of 400 to $450 \mathrm{mg} / 1$. Disposable, conical polypropylene centrifuge tubes with a total capacity of $50 \mathrm{ml}$ were used as culture vessels. Culture during the first $24 \mathrm{~h}$ was performed with $6 \mathrm{ml}$ of medium per 6 embryo units. After $24 \mathrm{~h}$ of culture, embryo units were transformed to new culture vessels and resuspended for a second 24-h period with $6 \mathrm{ml}$ of fresh culture medium, in which 6 embryo units for control or 2 embryo units for hypoglycaemic conditions were present. Culture medium was gassed with $5 \% \mathrm{O}_{2}$ and $5 \% \mathrm{CO}_{2}$ in $\mathrm{N}_{2}$ during the first $24 \mathrm{~h}$ of culture. Subsequent $1.5 \mathrm{~min}$ gassings were $20 \% \mathrm{O}_{2}$ and $5 \% \mathrm{CO}_{2}$ in $\mathrm{N}_{2}$ during the $24-40 \mathrm{~h}$ and $40 \% \mathrm{O}_{2}$ and $5 \% \mathrm{CO}_{2}$ in $\mathrm{N}_{2}$ during the $40-48 \mathrm{~h}$.

Embryo units were exposed to hypoglycaemia for different hours during the $48 \mathrm{~h}$ culture period. In the initial experiments, embryo units were exposed to hypoglycaemia throughout the 48-h period (from 0 to $48 \mathrm{~h}$ ). Other units were then exposed for the first $24 \mathrm{~h}$ only (from 0 to $24 \mathrm{~h}$ ) or the second $24 \mathrm{~h}$ only (from 24 to $48 \mathrm{~h}$ ). In another series of experiments, embryos (6 embryo units in $6 \mathrm{ml}$ of culture media) were exposed to hypoglycaemia for $8 \mathrm{~h}$ only during the first $24 \mathrm{~h}$ (from 0 to $8 \mathrm{~h}$, or from 8 to $16 \mathrm{~h}$ ) or during the second $24 \mathrm{~h}$ and cultured for a total of $48 \mathrm{~h}$. On day $11 \frac{1}{2}$ of gestation, i.e. at the end of the second $24 \mathrm{~h}$ period, embryo units were removed from the culture vessels. They were examined for heart beat and yolk sac circulation, then introduced into saline to separate the yolk sac and amnion from the embryo under a dissecting microscope. Overall growth and differentiation of embryos were quantified by direct measurement of crown-rump length and somite number respectively. Specific organs were evaluated for dysmorphogenesis by visual inspection, according to a detailed checklist. The morphologic examination of embryos was performed with an unawareness of the experimental protocol. Malformations were subdivided into two categories, neural and extraneural lesions. Neural lesions indicated specific lesions involving developments of neural plates such as open neurotubes, open neuropore fusion of anterior and posterior neural folds and brain malformations. Extraneural lesions include minor abnormalities such as defects in axial rotation or lesions involving the optic and otic vesicles, heart size, pericardial cavity or skeletal system [15]. After visual inspection, embryos and membranes were introduced into $0.5 \mathrm{~N}$ sodium hydroxide for estimation of the amount of total protein [17]. Aliquots were removed from the culture medium at the inception and termination of each $24-\mathrm{h}$ culture period and stored at $-15^{\circ} \mathrm{C}$ for subsequent enzymatic estimation of glucose [18] and lactic acid [19].

\section{Statistical analysis}

All data are presented as means \pm SEM. Intergroup differences in the frequency of morphologic lesions were assessed by Chi square analysis [26]. All other comparisons were performed using unpaired or paired Student's t-tests [26].

\section{Results}

Control embryos explanted at the early head-fold stage ( $9 \frac{112}{2}$ days of gestation) which underwent normal devel-

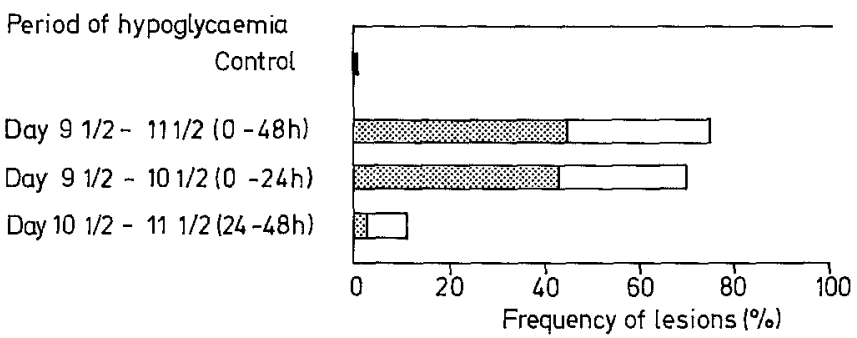

Fig. 1. Time relationships for the dysmorphogenic effect of hypoglycaemia. Embryos were explanted at $9 \frac{1}{2}$ day of gestation and cultured in control media containing $1100-1200 \mathrm{mg} / \mathrm{l}$ of glucose and hypoglycaemic media containing $400-450 \mathrm{mg} / 1$ of glucose throughout the $48 \mathrm{~h}$ of culture (day $9 \frac{1}{2}-11 \frac{1}{2}$ ) or the first (day $91 / 2-10 \frac{1}{2}$ ) or second $24 \mathrm{~h}$ (day 101/2-11/2) only. Forty-two to ninety-six embryos, as listed in Table 2, were examined for each group. 웅 Neural lesions; $\square$ Extraneural lesions

opment during the 48-h culture period were indistinguishable from those observed in vivo. These embryos showed a clearly delineated brain, completely closed neural tubes, well-formed otic and optic vesicles, normal heart development and completed axial rotation with a ventrally concave C-shaped curvature.

In contrast, embryos cultured in hypoglycaemic serum throughout $48 \mathrm{~h}$ of culture, exhibited greater frequencies of neural lesions $(44.4 \%, p<0.01)$ as well as extraneural lesions $(74.1 \%, p<0.01)$. The most prominent abnormalities were neural lesions consisting of open neural tubes and brain anomalies and other abnormalities including optic vesicles, heart, axial rotation were seen (Fig. 1).

To assess when the dysmorphogenic effects of hypoglycaemic serum were greatest, comparisons of the effects of hypoglycaemic serum throughout $48 \mathrm{~h}$ of culture (Day $9 \frac{1}{2}$ to $11 \frac{1}{2}$ ), with those of hypoglycaemic serum during the first $24 \mathrm{~h}$ only (Day $9 \frac{1}{2}$ to $10^{\frac{1}{2}}$ ) or the second $24 \mathrm{~h}$ only (Day 101/2 to $11 \frac{1 / 2}{2}$ ) were made. When embryos were incubated in serum from hypoglycaemic donors during the first $24 \mathrm{~h}$ of culture (Day $9 \frac{1 / 2}{2}$ to $10 \frac{1}{2}$ ), the frequencies of neural lesions were significantly greater $(42.7 \%, p<0.01)$ and were comparable with those observed after hypoglycaemic exposure for $48 \mathrm{~h}$ of culture (Day $9 \frac{1 / 2}{2}$ to $11 \frac{1}{2}$ ). However, on exposure to hypoglycaemic serum during the second $24 \mathrm{~h}$ of culture (Day 101/2 to $11 \frac{1}{2}$ ), significant frequencies of neural lesions were not found ( $2.4 \%, \mathrm{NS})$ (Fig. 1 ). In addition to the above findings, embryos incubated in serum from hypoglycaemic donors during the first $24 \mathrm{~h}$ of culture had much lower mean values for somite numbers $(p<0.01)$, crown-rump length $(p<0.01)$ and total protein $(p<0.01)$, whereas embryos after exposure to hypoglycaemic serum during the second $24 \mathrm{~h}$ of culture revealed slightly but significantly reduced values for crown-rump length $(p<0.01)$, compared to control embryos (Table 1). In embryos incubated in serum from normal donors during the first $24 \mathrm{~h}$ of culture, utilised glucose was converted to lactic acid (95 $\pm 2 \%)$, 
Table 1. Effects of hypoglycaemia on growth of embryo

\begin{tabular}{|c|c|c|c|c|}
\hline $\begin{array}{l}\text { Periods of } \\
\text { hypoglycaemia }\end{array}$ & No. & $\begin{array}{l}\text { Crown to } \\
\text { rump } \\
(\mathrm{mm})\end{array}$ & $\begin{array}{l}\text { Somites } \\
(n)\end{array}$ & $\begin{array}{l}\text { Protein } \\
(\mu \mathrm{g})\end{array}$ \\
\hline Control & 62 & $3.76 \pm 0.04$ & $28.9 \pm 0.1$ & $234 \pm 3$ \\
\hline $\begin{array}{l}\text { Day } 9 \frac{1 / 2-11 \frac{1}{2}}{}(0-48 \mathrm{~h})\end{array}$ & 54 & $2.75 \pm 0.11^{\mathrm{a}}$ & $25.0 \pm 0.6^{\mathrm{a}}$ & $171 \pm 8^{\mathrm{a}}$ \\
\hline $\begin{array}{l}\text { Day } 9 \frac{1 / 2}{2}-10^{1 / 2} \\
(0-24 \mathrm{~h})\end{array}$ & 96 & $3.20 \pm 0.07^{\mathrm{a}}$ & $26.2 \pm 0.4^{\mathrm{a}}$ & $187 \pm 6^{\mathrm{a}}$ \\
\hline $\begin{array}{l}\text { Day } 10^{1 / 2}-11^{1 / 2} \\
(24-48 \mathrm{~h})\end{array}$ & 42 & $3.50 \pm 0.07^{\mathrm{a}}$ & $28.5 \pm 0.2$ & $222 \pm 5^{\mathrm{a}}$ \\
\hline
\end{tabular}

Embryos were explanted on day $9 \frac{1}{2}$ of gestation and cultured for $48 \mathrm{~h}$ in normal rat serum and hypoglycaemic serum containing $400-450 \mathrm{mg} / \mathrm{l}$ of glucose throughout $48 \mathrm{~h}$ or first $24 \mathrm{~h}$ or second $24 \mathrm{~h}$ of culture. Values for crown to rump, somite number and protein were expressed as mean \pm SEM. ${ }^{a} p<0.01$ compared to control embryo

Table 2. Effect of supplement with glucose to hypoglycaemic serum and addition of insulin to normal serum on early embryogenesis

\begin{tabular}{|c|c|}
\hline No. & $\begin{array}{ll}\text { Frequen- } & \text { Crown to } \\
\text { cy } & \text { rump } \\
\text { of neural } & (\mathrm{mm}) \\
\text { lesions } & \\
(\%) & \end{array}$ \\
\hline
\end{tabular}

\begin{tabular}{lllll}
\hline $\begin{array}{l}\text { (I) Control serum } \\
\text { (II) Hypoglycaemic }\end{array}$ & 18 & 0 & $3.74 \pm 0.04$ & $28.7 \pm 0.2$ \\
serum + glucose & & & & \\
A) $300-350 \mathrm{mg} / 1$ & 18 & $55.6^{\mathrm{a}}$ & $2.80 \pm 0.11^{\mathrm{a}}$ & $23.7 \pm 0.9^{\mathrm{a}}$ \\
B) $500-550 \mathrm{mg} / 1$ & 18 & $33.3^{\mathrm{a}}$ & $3.31 \pm 0.10^{\mathrm{a}}$ & $27.7 \pm 0.4^{\mathrm{b}}$ \\
C) $750-800 \mathrm{mg} / 1$ & 18 & 0 & $3.48 \pm 0.03^{\mathrm{a}}$ & $28.7 \pm 0.1$ \\
D) $1000-1100 \mathrm{mg} / 1$ & 24 & 0 & $3.71 \pm 0.06$ & $28.8 \pm 0.4$
\end{tabular}

(III) Control

serum + insulin

$5000 \mu \mathrm{U} / \mathrm{ml}$

120

$3.67 \pm 0.04 \quad 28.5 \pm 0.2$

Embryo units were explanted on Day $9 \frac{1}{2}$ and incubated during first $24 \mathrm{~h}$ in the media (II), supplemented with various doses of glucose to the pooled serum from hypoglycaemic donors, which contained initial glucose concentrations of $300-350 \mathrm{mg} / 1$ (A), $500-550 \mathrm{mg} / \mathrm{l}$ (B), $750-800 \mathrm{mg} / \mathrm{l}$ (C) and 1000 to $1100 \mathrm{mg} / \mathrm{l}$ (D) and in the media (III) added with insulin at the concentration of $5000 \mu \mathrm{U} / \mathrm{ml}$ to serum from normal donors. These were followed during the second $24 \mathrm{~h}$ by the serum from normal donors and examined for gross dysmorphogenesis on day $11 \frac{1}{2}$. Values for crown to rump and somite are expressed as mean \pm SEM. ${ }^{a} p<0.01 ;{ }^{b} p<0.05$ compared to control

Table 3. Effects of exposure of hypoglycaemia for $8 \mathrm{~h}$

\begin{tabular}{lccll}
\hline $\begin{array}{l}\text { Periods of } \\
\text { hypoglycaemia }\end{array}$ & No. & $\begin{array}{l}\text { Frequency } \\
\text { of neural } \\
\text { lesions } \\
(\%)\end{array}$ & $\begin{array}{l}\text { Crown to } \\
\text { rump } \\
(\mathrm{mm})\end{array}$ & $\begin{array}{l}\text { Somites } \\
(n)\end{array}$ \\
\hline Control & 42 & 0 & $3.72 \pm 0.04$ & $28.6 \pm 0.1$ \\
$0-8$ h culture & 54 & $9.3^{\mathrm{a}}$ & $3.33 \pm 0.05^{\mathrm{b}}$ & $27.7 \pm 0.3^{\mathrm{a}}$ \\
$8-16 \mathrm{~h}$ culture & 60 & $13.3^{\mathrm{a}}$ & $3.32 \pm 0.06^{\mathrm{b}}$ & $27.3 \pm 0.2^{\mathrm{b}}$ \\
\hline
\end{tabular}

Embryos were explanted on Day $91 / 2$ of gestation and exposed to hypoglycaemia for $8 \mathrm{~h}$ (from 0 to $8 \mathrm{~h}$ or 8 to $16 \mathrm{~h}$ ) during the first $24 \mathrm{~h}$ of culture periods and dysmorphogenesis was examined after $48 \mathrm{~h}$ of culture. Values for crown to rump and somite number were expressed as mean \pm SEM. ${ }^{\mathrm{a}} p<0.05 ;{ }^{\mathrm{b}} p<0.01$ compared to control embryos confirming previous reports [16, 25]. Embryos incubated with serum from hypoglycaemic donors during first $24 \mathrm{~h}$ of culture showed significantly lower glucose uptake and lactic acid release than those with serum from normal donors (glucose uptake: $241 \pm 16 \mu \mathrm{g}$ versus $433 \pm 27 \mu \mathrm{g}, p<0.01$; lactic acid release: $230 \pm 13 \mu \mathrm{g}$ versus $424 \pm 36 \mu \mathrm{g}, p<0.01$; as expressed $\mu \mathrm{g} /$ embryo unit/24 h).

To examine further the relationship of malformations to depletion of glucose in culture media, embryos were incubated during the first $24 \mathrm{~h}$ in the media, supplemented with various doses of glucose to the serum from hypoglycaemic donors. Embryos cultured in severely and moderately glucose-depleted media at the initial glucose concentrations of 300 to $350 \mathrm{mg} / 1$ and 500 to $550 \mathrm{mg} / 1$ exhibited greater frequencies of neural tube defects $(55.6 \% p<0.01$, and $33.3 \%, p<0.01$, respectively) in combination with growth retardation with decreased values of crown to rump and somite numbers. On the other hand, an addition of sufficient glucose at the initial glucose concentrations of $750-800 \mathrm{mg} / 1$ and $1000-1100 \mathrm{mg} / 1$, showed no neural tube defects and were almost restored from growth retardation, in which slight but significant reduced crown-rump length $(p<0.01)$ was still observed in the media containing a glucose concentration of $750-800 \mathrm{mg} / 1$ (Table 2). Embryos cultured in the media containing glucose at the concentrations of $300-350 \mathrm{mg} / 1$ and $500-550 \mathrm{mg} / 1$ showed significantly lower glucose uptake $(220 \pm 31 \mu \mathrm{g}, p<0.01$ and $307 \pm$ $3 \mu \mathrm{g}, \quad p<0.01$, respectively) and lactic acid release $(205 \pm 31 \mu \mathrm{g}, p<0.01$ and $283 \pm 10 \mu \mathrm{g}, p<0.01$, respectively), whereas those cultured at the concentrations of $750-800 \mathrm{mg} / 1$ and $1000-1100 \mathrm{mg} / 1$ showed a statistically significant decrease compared with the control (glucose uptake: $433 \pm 9 \mu \mathrm{g}$, NS, and $435 \pm$ $12 \mu \mathrm{g}$, NS, versus $443 \pm 9 \mu \mathrm{g}$; lactic acid release: $396 \pm 4 \mu \mathrm{g}$, NS, $413 \pm 12 \mu \mathrm{g}$, NS, versus $416 \pm 13 \mu \mathrm{g}$, as expressed $\mu \mathrm{g} /$ embryo unit $/ 24 \mathrm{~h}$ ).

Even the addition of insulin at the concentration of $5000 \mu \mathrm{U} / \mathrm{ml}$ directly to serum from normal rats did not have adverse effects on embryogenesis (Table 2). Additional experiments were performed to examine effects of hypoglycaemic serum for a relatively short period $(8 \mathrm{~h})$ during the first $24 \mathrm{~h}$ as well as the second $24 \mathrm{~h}$ of culture. Cultured embryos were exposed to hypoglycaemic serum for $8 \mathrm{~h}$ during the first $24 \mathrm{~h}$ from 0 to $8 \mathrm{~h}$ or 8 to $16 \mathrm{~h}$ and examined after a total of $48 \mathrm{~h}$ of culture. Even exposure to hypoglycaemic serum from 0 to $8 \mathrm{~h}$ or 8 to $16 \mathrm{~h}$ resulted in neural lesions at the frequency of $9.3-13.3 \%$ (Table 3, Fig. 2). These embryos also showed decreased mean values of crown-rump length $(p<0.05)$ and somite numbers $(p<0.01)$, compared with control embryos (Table 3 ). Exposure to hypoglycaemic serum for $8 \mathrm{~h}(24-32 \mathrm{~h}$ or $32-40 \mathrm{~h})$ during the second $24 \mathrm{~h}$ showed no neural lesions although minor growth retardation existed (data are not shown). Net glucose uptake and lactic acid release in the hypo- 


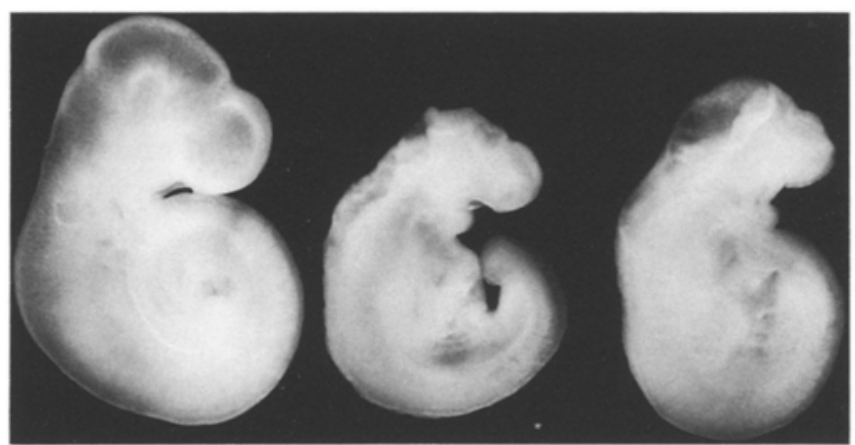

Fig. 2. Dysmorphogenic effects of hypoglycaemia. The illustration depicts embryos at $11 \frac{1}{2}$ days of gestation after $48 \mathrm{~h}$ of culture in control media (as shown by embryo on the left) or in hypoglycaemic exposure for $8 \mathrm{~h}$ (as shown by 2 embryos on the right)
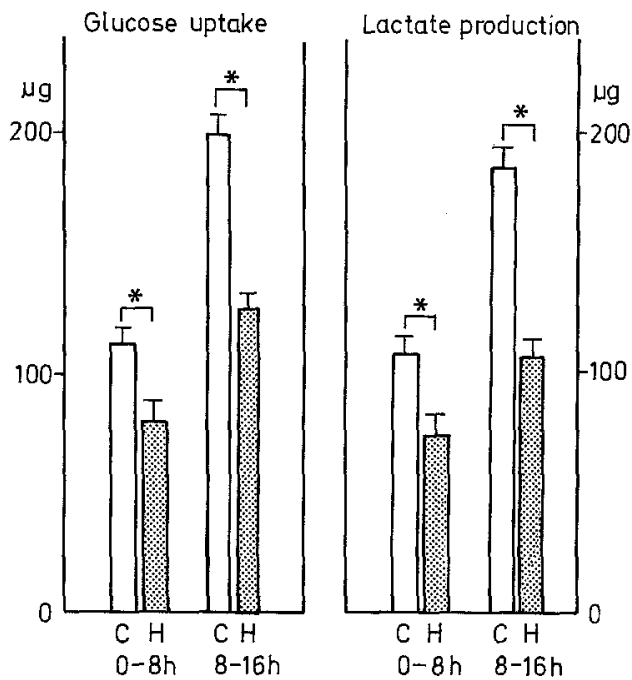

Fig.3. Glucose uptake and lactic acid release in exposure to hypoglycaemic serum for $8 \mathrm{~h}$. Six embryo units in $6 \mathrm{ml}$ of media were cultured with control $(\mathrm{C})$ and hypoglycaemic serum $(\mathrm{H})$ for the first $8 \mathrm{~h}$ $(0-8 \mathrm{~h})$ or the second $8 \mathrm{~h}(8-16 \mathrm{~h})$. The data are given as mean \pm $S E M$ in $\mu \mathrm{g}$ of glucose uptake and lactic acid release per embryo unit in $8 \mathrm{~h} .{ }^{*} p<0.01$ compared to control. The initial levels of glucose and lactic acid were $1155 \pm 32 \mathrm{mg} / 1$ and $356 \pm 15 \mathrm{mg} / 1$ in control serum, and $415 \pm 3 \mathrm{mg} / 1$ and $251 \pm 8 \mathrm{mg} / 1$ in hypoglycaemic serum respectively. The respective final levels were $1040 \pm 31 \mathrm{mg} / 1$ and $464 \pm 13 \mathrm{mg} / 1$ in control serum, and $336 \pm 6 \mathrm{mg} / 1$ and $326 \pm 8 \mathrm{mg} / 1$ in hypoglycaemic serum after the first $8 \mathrm{~h}$ incubation, and $955 \pm$ $25 \mathrm{mg} / 1$ and $540 \pm 9 \mathrm{mg} / 1$ in control serum and $285 \pm 5 \mathrm{mg} / 1$ and $378 \pm 6 \mathrm{mg} / 1$ in hypoglycaemic serum after the second $8 \mathrm{~h}$ incubation

glycaemic serum were reduced by approximately $30 \%-40 \%$, compared with control serum (Fig. 3).

\section{Discussion}

In the present study, we have investigated the effects of hypoglycaemia on cultured rat embryos undergoing organogenesis from the early head-fold stage to the 26 to 30 somite stage (day $9 \frac{1}{2}$ to $11 \frac{1 / 2}{2}$ of gestation). We demonstrated that on exposure to hypoglycaemic se- rum during the first $24 \mathrm{~h}$ of culture (day $9 \frac{1}{2}$ to $101 / 2$ ), embryos showed marked growth retardation and increased frequencies of neural lesions, in contrast to hypoglycaemic exposure during the second $24 \mathrm{~h}$ of culture, where only minor growth retardation and very low frequencies of neural lesions were seen. Thus, hypoglycaemia during critical periods of embryogenesis can adversely affect embryonic development.

Most prominent abnormalities produced in this experiment were neural-tube defects in combination with overall growth retardation. Congenital lesions produced in this experiment constitute both neural and extraneural lesions. Extraneural lesions were often less reproducible and included relatively minor abnormalities. With regards to neural tissue, the neural plate is established on day $9 \frac{1}{2}$ of gestation. Normally, the raising and subsequent apposition of the neural fold is followed by neural-tube formation. The anterior neuropore is closed by day $10^{1 / 2}$ and the posterior neuropore is closed on day 11.3, with complete closure of the neural-tube. Therefore, incomplete closure of the neuraltube after $48 \mathrm{~h}$ of culture represents specific dysmorphogenesis. Furthermore, embryos with gross dysmorphogenesis exhibited general growth retardation with decreased values of crown to rump length, somite numbers and total protein. This finding is consistent with the hypothesis that early growth retardation in human pregnancy may predispose the fetus to congenital malformations [20-21].

The lesions produced in this study are very similar to those of in vivo animal experiments where hypoglycaemia during pregnancy by fasting and administration of insulin was associated with exencephaly and skeletal abnormalities in the offspring $[22,23]$.

The age-related effects of hypoglycaemia may be related to glucose metabolism in embryos during neural-tube formation. Earlier studies have indicated that glycolysis constitutes the chief energy source for the post-implantation embryo before establishment of allantoic placenta circulation on day $10 \frac{1}{2}$, where a high rate of glycolysis was characterised and almost all utilised glucose was metabolised to lactic acid [16, 25]. During the following day (day 11), Krebs cycle activity is operative with establishment of allantoic circulation, which requires much less glucose and efficiently yields more higher energy phosphate. It has been reported that addition of $1.5 \mathrm{mg} / \mathrm{ml}$ mannose to incubation media during the first $24 \mathrm{~h}$ of culture (day $91 / 2$ to $10 \frac{1}{2}$ ), by which interference of glycolytic process was caused at this time, resulted in generalised growth retardation and neural tube defects in about half of exposed rat embryos (Honeybee syndrome) [15-16].

Our study is very similar to the findings of teratogenic effects of mannose on rat embryo culture. In the present study, when embryos were incubated in serum from hypoglycaemic rats during first $24 \mathrm{~h}$ of culture, glucose uptake and lactic acid release were reduced significantly (Fig.3), indicating a decrease of energy 
production via glycolysis. In additional experiments to examine the relationship of malformation to glucosedepletion in culture media, embryos incubated in severe glucose-depleted media showed a higher incidence of neural lesions and marked growth retardation, whereas those incubated in the media supplemented sufficiently with glucose to hypoglycaemic serum, those incubated reveal no neural tube defects with almost normal developement (Table 2). Thus glucopoenia during periods that are dependent on glycolysis for major energy production may be an important factor to cause neural lesions and growth retardation. Embryos incubated in medium containing glucose at the concentration of $750-800 \mathrm{mg} / 1$ showed minor growth retardation (Table 2). With regard to factors involved in hypoglycaemic serum which might have adverse affects on embryonic developement, it does not appear that insulin itself plays a direct role. It has been reported that specific insulin binding was demonstrable in rat embryo at day 10.4 [31] and exogenous insulin administered to chick embryo had teratogenic effects $[27,28,32]$; but the addition of insulin directly to serum from normal rats in our experiment did not show dysmorphogenesis (Table 2), confirming a previous report [30]. This may be due to a difference of sensitivity to insulin between mammalian and avian embryo, or doses or procedure of insulin administration. Factors other than glucose that may have an effect on embryogenesis may include growth factors or counterregulatory hormones induced by insulin injection. Growth factors such as the somatomedin and epidermal growth factors have been demonstrated in embryonic fetal tissues. The earliest detection of receptor for somatomedin $\mathrm{C}$ has been at day 10 for mouse embryo [37] and for epidermal growth factor receptors at day 12 [38]. The findings that somatomedin inhibitors from diabetic rat serum retarded growth and development in rat [36] and mouse [35] embryos suggest a possible role of somatomedin in early embryonic development. We can not exclude the possibility that decreased activity of somatomedin [34] and increased counterregulatory hormones [33] in insulin-induced hypoglycaemic serum may have been involved as well.

A number of clinical [8, 30] and experimental [6] studies have demonstrated that poorly controlled maternal diabetes has been associated with an increased incidence of birth defects in offspring. Meticulous diabetic control has reduced the risk of the occurrence of congenital anomalies in the offspring of diabetic rats $[6,30]$ and humans [29]. Thus metabolic abnormalities occurring in the diabetic state might be the most important factors causing congenital malformation. In addition, the present experiment demonstrated that hypoglycaemia during the critical developing periods had a deleterious effect on rat embryogenesis. However, it should be pointed out that our study on embryos exposed to insulin-induced hypoglycaemic serum for $8 \mathrm{~h}$ might not be directly extrapolated to human diabetic pregnancy. Further experiments on brief hypoglycaemia will be needed. Experiments are now in progress in our laboratory to determine whether or not brief hypoglycaemia $(1 \mathrm{~h})$ during the critical periods has adverse effects on embryogenesis in rat embryo culture [39].

Acknowledgements. The authors are grateful to Dr. L.F. Kumagai, University of California, Davis, California, USA, for reviewing this manuscript.We wish to thank Miss M.Nishimura for technical assistance.

\section{References}

1. Milis JL (1982) Malformations in infants of diabetic mothers. Teratology 25: 385-394

2. Soler NG, Walsh CH, Malins JM (1976) Congenital malformations in infants of diabetic mothers. $Q \mathrm{~J}$ Med 45: 303-313

3. Pedersen LM, Tygstrup I, Pedersen J (1964) Congenital malformations in newborn infants of diabetic women: correlations with maternal diabetic vascular complications. Lancet I: 1124-1126

4. Day R, Insley J (1976) Maternal diabetes mellitus and congenital malformation. Arch Dis Child 51: 935-938

5. Horii K, Watanabe G, Ingalls TH (1966) Experimental diabetes in pregnant mice. Diabetes 15: 194-204

6. Eriksson U, Dahlstrom E, Larsson KS, Hellerstrom C (1982) Increased incidence of congenital malformations in the offspring of diabetic rats and their prevention by maternal insulin therapy. Diabetes 31: 1-6

7. Leslie RDG, Pyke DA, John PN, White JM (1978) Hemoglobin A1 in diabetic pregnancy. Lancet II: 958-959

8. Miller EM, Hare JW, Cloherty JR, Dunn PJ, Gleason RE, Soeldner JS, Kitzmiller JL (1981) Major congenital anomalies and elevated $\mathrm{HbA1c}$ in early weeks of diabetic pregnancy in infants of diabetic mothers. N Engl J Med 304: 1331-1334

9. New DAT (1978) Whole embryo culture and the study of mammalian embryos during organogenesis. Biol Rev 53: 81-122

10. New DAT, Coppola PT, Cockroft DL (1976) Improved development of head-fold rat embryos in culture resulting from low oxygen and modifications of the culture serum. J Reprod Fertil 48: 219-222

11. Sadler TW (1980) Effect of maternal diabetes on early embryogenesis: II Hyperglycemia-induced exencephaly. Teratology 21: 349-356

12. Garnham EA, Beck F, Clarke CA, Stanisstreet M (1983) Effects of glucose on rat embryos in culture. Diabetologia 25:291-295

13. Horton WE, Salder TW (1983) Effect of maternal diabetes on early embryogenesis: alternations in morphogenesis produced by ketone body, B-hydroxybutyrate. Diabetes 32: 610-616

14. Lewis NJ, Akazawa S, Freinkel N (1983) Teratogenesis from Bhydroxybutyrate during organogenesis in rat embryo organ culture and enhancement by subteratogenic glucose. Diabetes 32 [Suppl]: 11 (Abstract)

15. Freinkel N, Lewis NJ, Akazawa S, Gorman L, Potaczek M (1983) The honeybee syndrome: teratogenic effects of mannose during organogenesis in rat embryo culture. Trans Assoc Am Physicians $96: 44-55$

16. Freinkel N, Lewis NJ, Akazawa S, Roth I, Gorman L (1984) The honeybee syndrom-implication of the teratogenecity of mannose in rat-embryo culture. $N$ Engl J Med 310: 223-230

17. Lowry OH, Rosenbrough NI, Farr AL, Randall RJ (1951) Protein measurement with the Folin Phenol reagent. J Biol Chem 193: 265-275

18. Bergmeyer HU, Bernt E, Schmidt H, Stork H (1974) D-Glucose: determination with hexokinase and glucose-6-phosphate dehydrogenase. In: Bergmeyer HU (ed) Methods of enzymatic analysis. Academic Press, New York, pp 1196-1201 
19. Gutmann I, Wahlefeld AW (1974) L-(+)-Lactate: determination with lactate dehydrogenase and NAD. In: Bergmeyer HU (ed) Method of enzymatic analysis. Academic Press, New York, pp 1464-1468

20. Pedersen JF, Mølsted-Pedersen L (1981) Early fetal growth delay detected by ultrasound marks increased risk of congenital malformation in diabetic pregnancy. Br Med J 283: 269-271

21. Spiers PS (1982) Does growth retardation predispose the fetus to congenital malformation? Lancet I: 312-314

22. Lichtenstein H, Guest GM, Warkany $J$ (1951) Abnormalities in offspring of white rats given protamine zinc insulin during pregnancy. Proc Soc Exp Biol Med 78: 398-402

23. Hannah RS, Moore KL (1971) Effects of fasting and insulin on skeletal development in rat. Teratology 4: 135-140

24. Smithberg M, Runner MN (1963) Teratogenic effects of hypoglycemic treatments in inbred strains of mice. Am $J$ Anat 113: 479-489

25. Shepard TH, Tanimúra T, Robkin MA (1970) Energy metabolism in early mammalian embryos. Symp Soc Dev Biol 29: 42-58

26. Snedecor GW, Cochran WG (1980) Statistical Methods, 7th edn. Iowa State University Press, Ames, Iowa, pp 64-130

27. Landauer W (1945) Rumplessness of chicken embryos produced by the injections of insulin and other chemicals. J Exp Zool 98: 65-77

28. Zilling E (1959) Micromelia as a direct effect of insulin. Evidence from in vitro and in vivo experiments. J Morphol 104: 159-179

29. Fuhrmann K, Reicher H, Semmler K, Fisher F, Fisher M, Glockner E (1983) Prevention of congenital malformations in infants of insulin-dependent diabetic mothers. Diabetes Care 6: 219-223

30. Sadler TW, Horton WE (1983) Effects of maternal diabetes on early embryogenesis. The role of insulin and insulin therapy. Diabetes 32: 1070-1074

31. Unterman T, Goewert RR, Baumann G, Freinkel N (1986) Insulin receptors in embryo and extra-embryonic membranes of early somite rat conceptus. Diabetes 35: 1193-1199

32. De Pablo F, Hernandez E, Collia F, Gomez JA (1985) Untoward effects of pharmacological doses of insulin in early chick embryos: through which receptor are they mediated? Diabetologia 28: 308-313
33. Phillipe M, Kitzmiller JL (1981) The fetal and maternal catecholamine response to insulin-induced hypoglycemia in the rat. Am J Obstet Gynecol 139: 407-415

34. Hill DJ, Potter JM, Cullen DR, Milner RDG (1981) Rapid changes in somatomedin activity during insulin-induced hypoglycemia: possible release of an inhibitory factor. $\mathrm{J}$ Clin Endocrinol Metab 53: 439-442

35. Sadler TW, Phillips LS, Balkan W, Goldstein S (1986) Somatomedin inhibitors from diabetic rat serum after growth and development of mouse embryos in culture. Diabetes 35: 861-865

36. Freinkel N, Cockroft DL, Lewis NJ, Gorman L, Akazawa S, Phillips LS, Shambaugh GE (1986) The 1986 McCollum award lecture. Fuel-mediated teratogenesis during early organogenesis: the effects of increased concentrations of glucose, ketones, or somatomedin inhibitor during rat embryo culture. Am J Clin Nutr 44: 986-995

37. D'Ercole AJ, Underwood LE (1980) Ontogeny of somatomedin during development in the mouse: serum concentrations, molecular forms, binding proteins and tissue receptors. Dev Biol 79: 33-45

38. Adamson ED, Merk J (1984) The ontogeny of epidermal growth factor receptors during mouse development. Dev Biol 103: 62-70

39. Akazawa $S$, Akazawa M, Hashimoto $M$, Mori T, Yamaguchi $Y$, Nakanishi T, Ueda Y, Yokota A, Miyake S, Nagataki S (1987) Enhancement of embryotoxic effects of brief hypoglycemia by hyperglycemia during organogenesis in rat embryo culture. Diabetes 36 [Suppl]: 91 (Abstract)

Received: 10 November 1986

and in revised form: 10 June 1987

Dr. Soichi Akazawa

First Department of Internal Medicine

Nagasaki Univ. School of Medicine

Nagasaki 852

Japan 